\title{
Relationship of lameness to body condition score, udder health and milk quality in crossbred dairy cattle
}

\author{
Amandeep Singh, Swaran Singh*, Dhiraj K. Gupta, \\ and Baljinder K. Bansal \\ Department of Veterinary Medicine, Guru Angad Dev Veterinary and Animal Sciences University, \\ Ludhiana, Punjab, India
}

SINGH, A., S. SINGH, D. K. GUPTA, B. K. BANSAL: Relationship of lameness to body condition score, udder health and milk quality in crossbred dairy cattle. Vet. arhiv 88, 179-190, 2018.

\section{ABSTRACT}

Three hundred and thirty-seven (337) crossbred dairy cows, at different stages of lactation and parity, from thirteen randomly selected dairy farms, were examined for locomotion score based on a five-point numerical scoring scale. Mild, moderate and severely lame cows were grouped together into the lame group and normal cows with locomotion score ' 0 ' into the healthy non-lame group. Body condition score (BCS) in all the animals was also evaluated on a five-point scale ranging from 1 to 5 . Cows having cow hock rear leg view (RLV) were assigned score ' 1 ', and score ' 0 ' for those with normal hocks. A quarter foremilk (QFM) and cow composite (CC) sample were collected from each cow maintaining aseptic conditions. QFM was used to determine the quarter health status of the cows, and CC for estimation of somatic cell count (SCC) and milk composition, in terms of fat, SNF, protein and lactose. It was concluded that lame cows had significantly $(\mathrm{P}<0.01)$ more milk SCC and poor quarter health status as compared to healthy cows. RLV increased with increasing lameness, although it did not affect milk SCC and composition. Likewise, milk composition was not affected by lameness. Lame cows had poor BCS, indicating a negative correlation with lameness.

Key words: lameness; body condition score; rear leg view; milk SCC; milk composition

\section{Introduction}

Lameness is a herd problem of crossbred dairy cattle, having serious implications for animal health, welfare, production and reproduction. Severe pain in lame cows compromises the normal lying and rising behaviour of cattle. Longer lying time in lame cows increases chances of mastitis (ITO et al., 2010). It has been observed that continuous

\footnotetext{
${ }^{*}$ Corresponding author:

Prof. Dr. Swaran Singh Randhawa, Department of Veterinary Medicine, Guru Angad Dev Veterinary and Animal Sciences University, Ludhiana-141 001, Punjab, India, Phone: +94 63242 612; +91 01612414 008; Fax: 910161 2400 822; E-mail: drswaran68@gmail.com
} 
A. Singh et al.: Relationship of lameness to body condition score, udder health and milk quality in crossbred dairy cattle

lying down could result in incomplete nutrition, resulting in loss of body weight and a lower rank in the hierarchy (GOMEZ and COOK, 2010).

Some studies have revealed that lameness reduces milk yield (READER et al., 2011), while others did not observe such an effect (ROWLANDS and LUCEY, 1986) or established even greater milk yields in cows with lameness (BARKEMA et al., 1994). Production losses associated with cases of lameness in cattle have been reported between 314-424 kg per lactation (BICALHO et al., 2008). A positive relationship was observed between poor foot health and a high incidence of clinical mastitis (ARVIDSON, 2000). A similar relationship between poorly trimmed hooves, lameness, milk yield and lying and rising behaviour was also reported by RAJALA-SCHULTZ et al. (1999).

PEELER et al. (1994) reported a 1.4 fold increase in the odds of clinical mastitis, and subsequently SCC, in clinically lame animals. Bacterial contamination of bedding might be a link between infection of the tarsus and udder (SOGSTAD et al., 2006). A close relationship between lameness and occurrence of mastitis affects the cows' productivity (COOK and NORDLUND, 2003). The degree of body dirt also predisposes to subclinical mastitis (VASILEV et al., 2007). MITEV (1998) observed that 5.5 percent of cows with subclinical mastitis also had hoof diseases. All factors predisposing to mastitis, including increased herd size, increased time of stall rearing etc. are also factors for development of lameness (LOGUE and BERGSTEN, 2007). Milk composition was also affected by lameness in crossbred dairy cattle. A significant decrease in mean monthly milk production, as well as in fat, protein, and lactose production in cows with clinical lameness, as compared to non-lame cows, was detected by OLECHNOWICZ and JACEKOWSKI (2010). The present study therefore was envisaged to investigate the relationship between lameness and udder health and milk quality in crossbred dairy cows, in an Indian context.

\section{Material and methods}

Selection of animals and management practices. The study involved 337 Holstein Friesian-Sahiwal crossbred cows at different stages of lactation and parity, from 13 randomly selected (THRUSFIELD, 2007) dairy farms in Punjab, using a two-stage sampling technique. All the farms were well-managed and organized farms. At 11 farms, milking was done by machine whereas on 2 farms, hand milking was practiced. Hoof trimming was not done routinely on all the farms but selectively in clinically lame animals. Seasonal fodder includeed legumes such as Lucerne (Medicago sativa) and Berseem (Trifolium alexandrium), grown in Rabi season and non-legumes such as Sorghum (Sorghum vulgare), Maize (Zea mays) and Bajra (Pennisetum typihoideus) grown in the Kharif season. Dry roughages included wheat straw and hay of Lucerne and Sorghum. Silage was fed on 11 farms out of 13, along with different non-legume fodders but there 
A. Singh et al.: Relationship of lameness to body condition score, udder health and milk quality in crossbred dairy cattle

was infrequent feeding with hay on the various farms. Mineral mixture supplementation was in practice on 11 farms.

Sampling and observations. On the day of milk sampling, each animal was allowed to walk on a flat surface and the gait of each animal was examined using a five-point numerical scoring scale. Score 0 was assigned for 'No gait abnormality', 1 for 'Mild lameness with slight disparity from normal gait symmetry', 2 for 'Moderate lameness with reasonable and constant gait asymmetry', 3 for 'Severe lameness with clear gait asymmetry or severe symmetric abnormality' and 4 for 'Non-ambulatory or recumbent status'.

The rear leg view index of each animal was observed as normal (score 0) when there was no inward knuckling of the hocks when seen from the rear and as cow hock (score 1) when there was inward knuckling of the hocks observed from the rear (RANDHAWA et al., 2008). Body condition score was evaluated on a five-point scale as described by FERGUSON et al. (1994).

Table 1. Body condition score scale

\begin{tabular}{|l|c|}
\hline Principle descriptive of body region & BCS \\
\hline Rump region has V shape & $>5$ \\
\hline Hook bone is rounded & 5 \\
\hline Hook and pin bones are angular. Pin bones have palpable fat pad & 4 \\
\hline Pin bones do not have palpable fat. Transverse processes of lumbar vertebrae are sharp & 3 \\
\hline Thurl is prominent and the cow has saw toothed spine & 2 \\
\hline Severely emaciated. All skeletal structures are visible & 1 \\
\hline
\end{tabular}

Milk samples were collected after proper disinfection of the teat surface with $70 \%$ ethanol. About $10 \mathrm{~mL}$ and $20 \mathrm{~mL}$ of quarter foremilk and cow composite samples, respectively, were collected aseptically in separate sterile containers after squirting a few initial streams. The milk samples were placed in an ice box and carried to the laboratory where they were kept at $4{ }^{\circ} \mathrm{C}$ in a refrigerator for further laboratory testing.

Analytical procedure used. Bacteriological examination of milk was performed as per the standard microbial procedures of the NATIONAL MASTITIS COUNCIL (1999). The California Mastitis Test was conducted and interpreted as per the standard method described by PANDIT and MEHTA (1969). The results were read as negative (-), trace, one plus $(+)$, two plus $(++)$ and three plus $(+++)$, depending upon the degree of gel formation. The somatic cell count in composite milk was analysed by a flow cytometry based automatic analyser (Somascope, Delta Instruments, Nether Lands) and the results were expressed in $\times 10^{3}$ cells $/ \mathrm{mL}$. Milk composition, in terms of fat, SNF, protein and lactose, was estimated by a milk analyzer (Lactoscan, Bulgaria) in percentages. 
A. Singh et al.: Relationship of lameness to body condition score, udder health and milk quality in crossbred dairy cattle

Table 2. Health status of the quarters based upon the milk culture results and the somatic cell count (CMT score) of the quarter foremilk samples

\begin{tabular}{|c|c|c|}
\hline \multirow{2}{*}{ CMT score } & \multicolumn{2}{|c|}{ Udder pathogen } \\
\cline { 2 - 3 } & Not detected & Detected \\
\hline$<1\left(\mathrm{SCC}<400 \times 10^{3}\right.$ cells $\left./ \mathrm{mL}\right)$ & Healthy & Latent infection \\
\hline$\geq 1\left(\mathrm{SCC}>400 \times 10^{3}\right.$ cells $\left./ \mathrm{mL}\right)$ & Non-specific mastitis & Specific mastitis \\
\hline
\end{tabular}

Statistical analysis. Data were analysed using MINITAB statistical software (Minitab Inc., Version 14.2) to analyse the relationship of lameness and milk quality. Cows having healthy and/or latent quarter health status were categorized in the healthy group. However, cows having at least one quarter with specific or non-specific mastitis were considered as the mastitis group. In relation to the stage of lactation, the cows were categorized as $<100$ days in milk, 100-200 days in milk and >200 days in milk, whereas regarding parity, cows were stratified into first, second plus third and fourth $\&$ above parity groups. Cows with a locomotion score ' 0 ' were grouped as non-lame and cows having locomotion scores 1 (mild), 2 (moderate) or 3 (severe) were considered as the lame group. Binary logistic regression was used to present the relationship between lameness and other variables more clearly, and to see the effect of even mild lameness on SCC. Data pertaining to somatic cell count (SCC) was log transformed (LnSCC) to obtain normal distribution, and descriptive statistics (mean, standard error) were calculated using the general linear method. Least squares means (LSM) were also calculated and compared. This is a mean estimated from a general linear model. In contrast, a raw or arithmetic mean is a simple average of values, using no model. Least squares means are adjusted for other terms in the model (like covariates), and are less sensitive to missing data. The results were expressed as statistically significant at $\mathrm{P}<0.05$.

\section{Results}

Forty percent of the 337 crossbred dairy cows were non-lame, 27\% had asymmetry or mild lameness, $25 \%$ had moderate lameness and $8 \%$ had severe lameness. About 34 percent of animals had BCS ranging between 2.0-2.5, 47\% had a BCS of 3 and 19\% of animals had BCS between 3.5 and 4 . Approximately $32 \%$ of dairy cows had cow hock rear leg view and nearly $68 \%$ had normal rear leg view. Knuckling of hocks was found to be more frequent in lame cows than in non-lame cows.

Subclinical mastitis was found in $64 \%$ of dairy cows. Associations between locomotion score, body condition score, rear leg view, parity, stage of lactation, quarter health status and various milk quality parameters were studied using a general linear model (Table 3). Lame cows were found to have higher milk SCC than non-lame cows (Fig. 1). 
A. Singh et al.: Relationship of lameness to body condition score, udder health and milk quality in crossbred dairy cattle

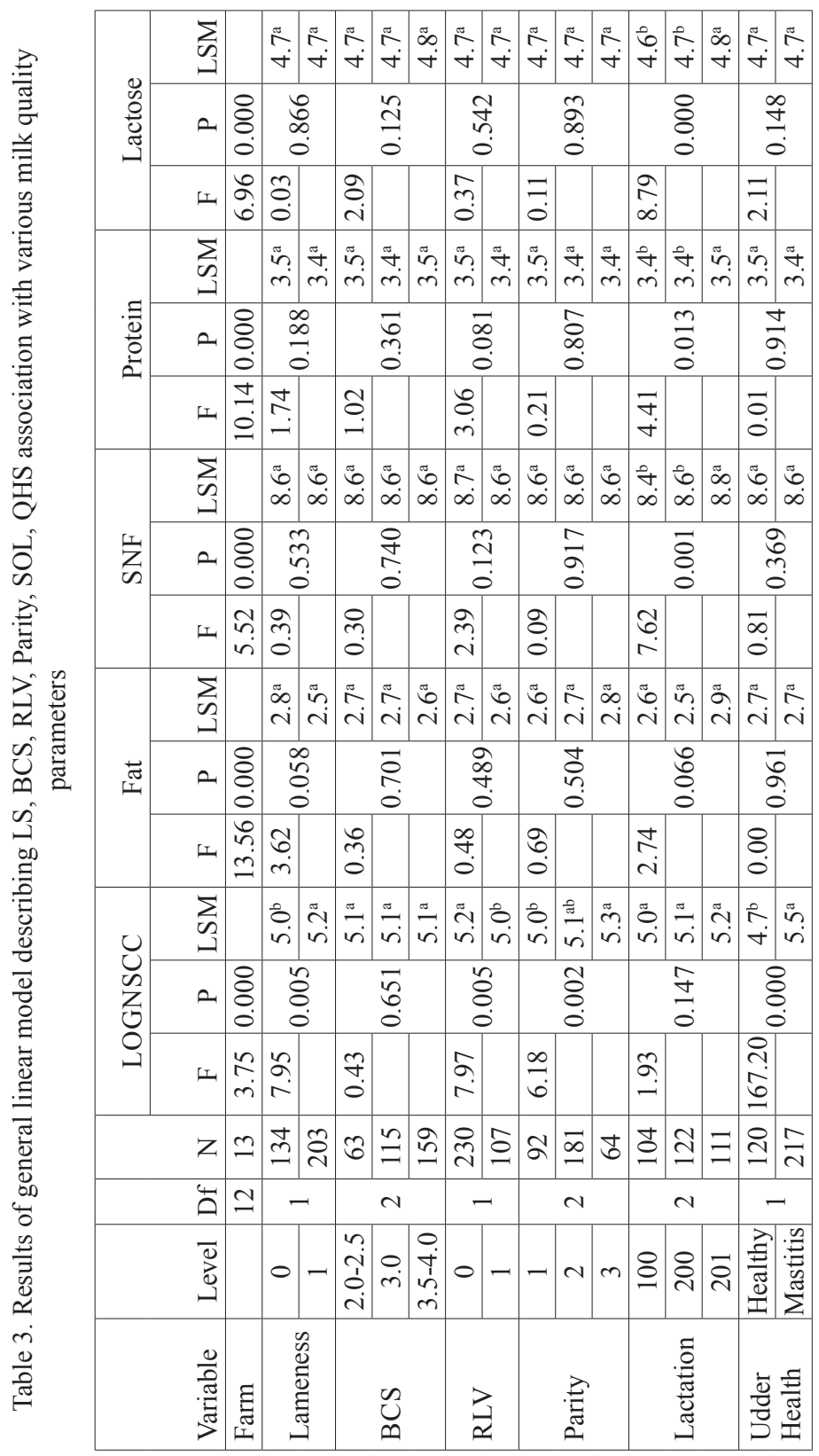


A. Singh et al.: Relationship of lameness to body condition score, udder health and milk quality in crossbred dairy cattle

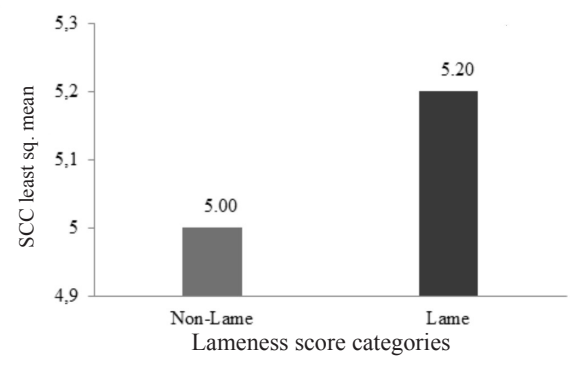

Fig. 1. Milk SCC in Lame and Non-Lame Cows

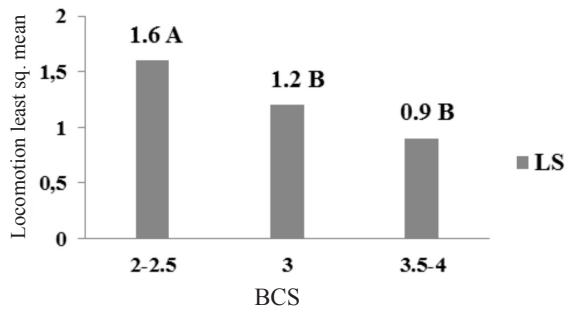

Fig. 2. Locomotion score versus Body Condition Score

With respect to milk composition, a non-significant variation was observed in fat percentage between lame and non-lame cows. In the present study, rear leg view was found to have a negative relationship with milk SCC. Cows with cow hock rear leg view were found to have significantly lower SCC as compared to cows with normal rear leg view. Similar to the lameness score, the rear leg view did not affect other milk composition factors, such as fat, SNF and protein. Similarly, the body condition score of the dairy cows did not have any relationship to milk composition factors such as fat, SNF, protein and lactose.

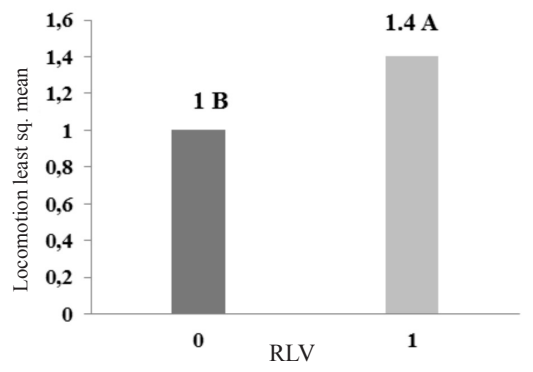

Fig. 3. Locomotion Score versus Rear Leg View (RLV)

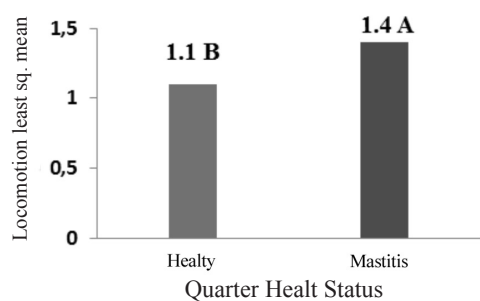

Fig. 4. Locomotion Score versus Quarter Health Status

With increasing parity, the milk SCC also increased due to loosening of the teat sphincter and exposure to multiple infections. SNF, protein and lactose percentages increased with the increase in the stage of lactation. However, milk SCC was not affected by the increase in the lactation stage. Similarly, quarters with subclinical mastitis were found to have higher milk SCC than healthy animals.

In the present study, it was found that lameness was significantly higher in early lactation than in the late lactation period. Animals with a high mean locomotion score were found to have lower body condition score, while animals with low locomotion score were found to have better body condition score (Fig. 2). However, a positive association 
A. Singh et al.: Relationship of lameness to body condition score, udder health and milk quality in crossbred dairy cattle

was found between locomotion score, rear leg view and udder health. Cow hock rear leg view was found to be more frequent in animals with a high locomotion score as compared to animals with a low locomotion score (Fig. 3). The odds of mastitis increased with an increase in locomotion score in the current study (Fig. 4) (Table 4).

Table 4. Binary logistic regression LS v/s BCS, RLV, Parity, Lactation, Udder health

\begin{tabular}{|c|c|c|c|c|c|c|}
\hline Variable & Level & Coeff. & $\mathrm{Z}$ & $\mathrm{P}$ & Odds Ratio & $95 \%$ CI \\
\hline \multirow{2}{*}{$\begin{array}{l}\mathrm{BCS} \\
\text { (reference } \leq 2.5 \text { ) }\end{array}$} & 3.0 & -1.47 & -3.38 & 0.001 & 0.23 & $0.10-0.54$ \\
\hline & $3.5-4$ & -1.94 & -4.54 & 0.000 & 0.14 & $0.06-0.33$ \\
\hline $\begin{array}{l}\text { RLV } \\
\text { (reference 0) }\end{array}$ & 1 & 1.18 & 4.14 & 0.000 & 3.26 & $1.86-5.70$ \\
\hline \multirow{2}{*}{$\begin{array}{l}\text { Parity } \\
\text { (reference group 1) }\end{array}$} & 2 & 0.017 & 0.06 & 0.951 & 1.02 & $0.58-1.77$ \\
\hline & 3 & 0.28 & 0.75 & 0.451 & 1.33 & $0.64-2.78$ \\
\hline \multirow{2}{*}{$\begin{array}{l}\text { Lactation } \\
(\text { reference } \leq 100)\end{array}$} & $\leq 200$ & 0.29 & 0.95 & 0.340 & 1.34 & $0.74-2.42$ \\
\hline & $>200$ & 0.24 & 0.78 & 0.436 & 1.27 & $0.69-2.35$ \\
\hline $\begin{array}{l}\text { Udder health } \\
\text { (reference healthy) }\end{array}$ & Mastitis & 0.512 & 1.94 & 0.052 & 1.67 & $0.99-2.80$ \\
\hline
\end{tabular}

\section{Discussion}

A poor body condition score was observed in severely lame animals. This was evident from the fact that nearly all the clinical/ severely lame animals (33\%) had BCS between 2.0 and 2.5. RANDALL et al. (2015) also observed a negative correlation between body condition score (BCS) and lameness in dairy cows. Poor body condition in lame animals might be due to pain associated with claw lesions, which further could alter the animal's lying behaviour. Due to alterations in lying behaviour, more time is spent lying down. In intensive management systems, animals are fed in mangers and the excessive lying behaviour of animals has a negative impact on body condition as the animal spends less time feeding, which results in inappropriate nutrition. BACH et al. (2007) observed that the time spent eating and the number of meals per day decreased as the locomotion score increased, resulting in a significant reduction in overall dry matter intake in most of the lame cows. However, RABER et al. (2004) reported that whether the body condition is high or low, both can equally make the animal susceptible to lameness due to the alteration in the fat of the digital cushion found in the hoofs of dairy cattle.

The number of animals with cow hock rear leg view was contiguous with the number of animals with moderate and severe lameness, indicating the positive correlation of cow hock rear leg view index with increasing lameness. ZAHID and RANDHAWA (2014) observed a significant association between locomotion scores and the rear leg view index, and found both tests equally reliable to identify clinical lameness on dairy farms, despite their subjective nature. Cow hock rear leg view was found to be more frequent in animals 
A. Singh et al.: Relationship of lameness to body condition score, udder health and milk quality in crossbred dairy cattle

with a high locomotion score as compared to animals with a low locomotion score. As most of the lesions were found on the lateral digits of the hind limbs, animals shifted weight onto the medial digits to minimize pressure on the lateral digits, usually seen as inward knuckling of the hocks (cow hock rear leg view).

Lame cows had a higher milk somatic cell count (SCC) than non-lame cows, with increased risk of mastitis. Increased lying time in lame cows might have exposed their udders to various intra-mammary infections, due to the close proximity to underfoot slurry. COULON et al. (1998) reported a non-infective inflammation induced by painful walking was found to be responsible for the elevated SCC. Similarly, OLECHNOWICZ and JACEKOWSKI (2010) reported that the source of increased milk SCC counts in clinically or severely lame cows was probably subclinical mastitis or lameness, and their synergistic stressful effect. However, in their subsequent study, OLECHNOWICZ and JACEKOWSKI (2012) observed no statistically significant difference in milk SCC between clinically lame cows and healthy cows. PEELER et al. (1994) and ARVIDSON (2000) suggested that the increased SCC in milk was a precipitating factor for occurrence of mastitis in lame cows. However, HULTGREN et al. (2004) found no relationship between lameness and udder health, and observed that only severe lameness impairs the cows' movements and increases the risk of teat injuries and subsequent mastitis. Contrary to the results of the above studies, ARCHER et al. (2011) and PAVLENKO et al. (2011) found a negative association between locomotion score and milk SCC. Lame cows were found to have lower milk SCC than non-lame cows, due to increased standing time in lame cows, causing the udders to be less exposed to intra-mammary infections.

The present study showed a non-significant variation in fat percentage between lame and non-lame cows, due to the fact that all the mild, moderate and severely lame animals were combined in the lame group which might have mitigated the effect of severe lameness, if there was any, on milk composition. However, OLECHNOWICZ and JACEKOWSKI (2010) noticed significantly lower mean monthly fat, protein, and lactose production in lame cows as compared to non-lame cows, due to stress, pain, increased oxidative agents, poor absorption and assimilation of various nutrients from daily diet due to lameness. In their successive trial, OLECHNOWICZ and JACEKOWSKI (2012) observed that clinical lame cows had significantly lower milk protein content as compared to healthy cows. Similarly, no change in milk composition was recorded between healthy, digital dermatitis affected cows and sole ulcers affected cows in a recent study (PAVLENKO et al., 2011).

Cows with cow hock rear leg view were found to have significantly lower SCC as compared to cows with normal rear leg view. The possible reason for this negative correlation is that the cow hock rear leg view could have some other aetiology other than 
A. Singh et al.: Relationship of lameness to body condition score, udder health and milk quality in crossbred dairy cattle

lameness alone. Similar to the lameness score, rear leg view and body condition scores did not affect other milk composition factors, such as fat, SNF and protein.

Lameness was found to be significantly higher in the early stages of lactation than in the late lactation period in the present study. The primary physiological changes during early lactation are glucose synthesis by hepatic gluconeogenesis, and decreased oxidation of glucose in peripheral tissues. Maintenance of cows in this period on a high concentrate diet eventually creates hyperinsulinaemia and hyperglycaemia (VERMUNT and GREENOUGH, 1994), a condition in which insulin resistance develops, resulting in inhibition of glucose and amino acid uptake, and producing poor quality hoof horn. However, HENDRY et al. (1999) identified the role of other factors, such as epidermal growth factor (EGF), relaxin, prolactin and cortisol levels at the time of late gestation that precipitate the production of poor quality keratin, thus leading to more likelihood of lameness during late lactation.

The significant improvement in the body condition scores with the increasing stages of lactation might be due to the subsequent decrease in milk yield, which allows the animal to conserve energy. The significant increase in locomotion score with increasing parity was similar to the findings of MANSKE et al. (2002) and SOGSTAD et al. (2005) who observed more lameness in multiparous cows as compared to primiparous cows. However, LISCHER et al. (2002) observed that heifers experienced more lameness due to major changes in housing conditions, their social environment, nutrition and physiological demands than senior lactating cows. It was also suggested that the tissues of the claws, such as the digital cushion might not be fully developed in heifers.

The odds of contracting mastitis increased with the increase in the locomotion score in the current study (Fig. 4). It was observed that lame cows tended to sit for a longer time causing the udder to be exposed to infections from underfoot slurry. These infections lead to an increase in milk SCC making the cows susceptible to subclinical or clinical mastitis. Similarly, RAJALA-SCHULTZ et al. (1999) suggested a significant association between poorly trimmed hooves, lameness, milk yield, and lying and rising behaviour. These might act as possible risk factors for teat infections leading to clinical mastitis (ELBERS et al., 1998).

From the present study, it was concluded that lame cows have higher milk SCC than non-lame healthy cows. A positive association was observed between lameness score and rear leg view, indicating more chances of cow hock rear leg view in lame cows. Lame cows exhibited a poor body condition score, indicating a negative correlation between body condition score and lameness score. Overall, the poor quarter health status of lame cows suggested that the odds of occurrence of mastitis are significantly higher in lame crossbred cows. However, there was no alteration in milk composition in lame cows. 
A. Singh et al.: Relationship of lameness to body condition score, udder health and milk quality in crossbred dairy cattle

\section{Acknowledgements}

The authors are thankful to the Dean, COVS and Director of Research, GADVASU for providing the facilities and funds to carry out this research. The authors also acknowledge the help given by the scientists and staff of the mastitis laboratory of the department in undertaking this study.

\section{References}

ARCHER, S. C., M. J. GREEN, A. MADOUASSE, J. N. HUXLEY (2011): Association between somatic cell count and serial locomotion score assessments in UK dairy cows. J. Dairy Sci. 94, 4383-4388.

ARVIDSON, A. K. (2000): Environmental and management factors associated with the incidence of clinical mastitis in high yielding dairy herds with a low incidence of subclinical mastitis. Graduate Report 136. Department of Animal Nutrition and Management, Swedish University of Agricultural Science, Uppsala, Sweden.

BACH, A., M. DINARES, M. DEVANT, X. CARRE (2007): Associations between lameness and production, feeding and milking attendance of Holstein cows milked with an automatic milking system. J. Dairy Res. 74, 40-46.

BARKEMA, H. W., J. D. WESTRIK, K. A. S. VANKEULEN, Y. H. SCHUKKEN, A. BRAND (1994): The effects of lameness on reproductive-performance, milk- production and culling in Dutch dairy farms. Prev. Vet. Med. 20, 249-259.

BICALHO, R. C., L. D. WARNICK, C. L. GUARD (2008): Strategies to analyse milk losses caused by diseases with potential incidence throughout the lactation: a lameness example. J. Dairy Sci. 91, 2653-2661

COOK, N. B., K. NORDLUND (2003): Interrelationships between housing and herd health. Advances Dairy Technol. 15, 85-95.

COULON, J. P., P. PRADEL, T. COCHARD, B. POUTREL (1998): Effect of extreme walking conditions for dairy cows on milk yield, chemical composition and somatic cell count. J. Dairy Sci. 81, 994-1003.

ELBERS, A. R. W., J. D. MILTENBURG, D. de LANGE, A. P. P. CRAUWELS, H. W. BARKEMA, Y. H. SCHUKKEN (1998): Risk factors for clinical mastitis in a random sample of dairy herds from the southern part of the Netherlands. J. Dairy Sci. 81, 420-426.

FERGUSON, J. D., D. T. GALligAN, N. THOMSEN (1994): Principal descriptors of body condition in Holstein dairy cattle. J. Dairy Sci. 77, 2695-2703

GOMEZ A., N. B. COOK (2010): Time budget of lactating dairy cattle in commercial free stall herds. J. Dairy Sci. 93, 5772-5781.

GREEN, L. E., V. J. HEDGES, Y. H. SCHUKKEN, R. W. BLOWEY, A. J. PACKINGTON (2002): The impact of clinical lameness on the milk yield of dairy cows. J. Dairy Sci. 85, 2250-2256.

HENDRY, K. A. K., A. J. MacCALLUM, C. H. KNIGHT, C. J. WILDE (1999): Effect of endocrine and paracrine factors on protein synthesis and cell proliferation in bovine hoof tissue culture. J. Dairy Res. 66, 23-33. 
A. Singh et al.: Relationship of lameness to body condition score, udder health and milk quality in crossbred dairy cattle

HULTGREN, J., T. MANSKE, C. BERGSTEN (2004): Associations of sole ulcer at claw trimming with reproductive performance, udder health, milk yield, and culling in Swedish dairy cattle. Prev. Vet. Med. 62, 233-251.

ITO, K., MAG VON KEYSERLINGK, S. J. LeBLANC, D. M. WEARY (2010): Lying behavior as an indicator of lameness in dairy cows. J. Diary Sci. 93, 3553-3560.

LISCHER, C. J., U. KOLLER, H. GEYER, C. MULLING, J. SCHULZE, P. OSSENT (2002): Effect of therapeutic dietary biotin on the healing of uncomplicated sole ulcers in dairy cattle - a double blinded controlled study. Vet. J. 163, 51-60.

LOGUE, D., C. BERGSTEN (2007): Lameness in cows - a welfare and profit reducing problem. Animal Health: Management and Control of Infectious and Production Diseases. B. Int. Dairy Fed. 416, 54-66.

MANSKE, T., J. HULTGREN, C. BERGSTEN (2002): The effect of claw trimming on the hoof health of Swedish dairy cattle. Prev. Vet. Med. 54, 113-129.

MITEV, J. (1998): Influence of nutrition and body condition score during dry period on the reproductive performance and health status of dairy cows after calving. Ph.D. Thesis. Trakia University, Stara Zagora.

NATIONAL MASTITIS COUNCIL (1999): Laboratory handbook on Bovine Mastitis. National Mastitis Council, Inc. 2820 Walton Commons West, Madison, USA.

OLECHNOWICZ, J., J. M. JASKOWSKI (2010): Impact of clinical lameness, calving season, parity, and month of lactation on milk, fat, protein, and lactose yields during early lactation of dairy cows. B. Vet. I. Pulawy. 54, 605-610.

OLECHNOWICZ, J., J. M. JASKOWSKI (2012): Relationship between clinical lameness and somatic cell counts, and fat and protein contents in the milk of dairy cows. Med. Weter. 68, 12.

PANDIT, A. V., M. L. MEHTA (1969): Sodium Lauryl Sulphate as a substitute for CMT reagent (California Mastitis test Reagent) for diagnosis of sub clinical mastitis in buffaloes. Indian Vet. J. 46, 111-119.

PAVLENKO, A., C. BERGSTEN, I. EKESBO, T. KAART, A. ALAND, L. LIDFORS (2011): Influence of digital dermatitis and sole ulcer on dairy cow behaviour and milk production. Anim. 5, 1259-1269.

PEELER, E. J., M. J. OTTE, R. J. ESSLEMONT (1994): Interrelationships of periparturient diseases in dairy cows. Vet. Rec. 134, 129-132.

RÄBER, M., C. J. LISCHER, H. GEYER., P. OSSENT (2004): The bovine digitalcushion - a descriptive anatomical study. Vet. J. 167, 258-264.

RAJALA-SCHULTZ, P. J., Y. T. GROHN, C. E. McCULLOCH (1999): Effects of milk fever, ketosis, and lameness on milk yield in dairy cows. J. Dairy Sci. 82, 288-294

RANDALL, L. V., M. J. GREEN, M. G. G. CHAGUNDA, C. MASON, S. C. ARCHER, L. E. GREEN, J. N., HUXLEY (2015): Low body condition predisposes cattle to lameness: An 8-year study of one dairy herd. J. Dairy Sci. 98, 3766-3777.

Vet. arhiv 88 (2), 179-190, 2018 
A. Singh et al.: Relationship of lameness to body condition score, udder health and milk quality in crossbred dairy cattle

RANDHAWA, S. S., K. DUA, C. S. RANDHAWA, S. S. RANDHAWA, S. K. MUNSHI (2008): Effect of biotin supplementation on hoof health and ceramide composition in dairy cattle. Vet. Res. Commun. 32, 599-608.

READER J. D., M. J. GREEN, J. KALER, S. A. MASON, L. E. GREEN (2011): Effect of mobility score on milk yield and activity in dairy cattle. J. Dairy Sci. 94, 5045-5052.

ROWLANDS, G. J., S. LUCEY (1986): Changes in milk-yield in dairy-cows associated with metabolic and reproductive disease and lameness. Prev. Vet. Med. 4, 205-221.

SOGSTAD, A. M., O. OSTERAS, T. FJELDAAS (2006): Bovine claw and limb disorders related to reproductive performance and production diseases. J. Dairy Sci. 89, 2519-2528.

SOGSTAD, Å. M., T. FJELDAAS, O. ØSTERÅS (2005): Lameness and claw lesions of the norwegian red dairy cattle housed in free stalls in relation to environment, parity and stage of lactation. Acta Vet. Scand. 46, 203-217.

THRUSFIELD, M. (2007): Veterinary Epidemology. $2^{\text {nd }}$ ed., UK Black Wellscience Ltd, pp. 182-198.

VASILEV, N., D. DINEV, Y. MITEV, M. KOLEVA, C. H. MITEVA (2007): Hygiene status of dairy cows reared in a spacious building and resulting quality of produced milk. Trakia J. Sci. $5,47-51$.

VERMUNT, J. J., P. R. GREENOUGH (1994): Predisposing factors of laminitis in cattle. Br. Vet. J. 150, 151-164.

ZAHID, U. N., S. S. RANDHAWA (2014): Association between lameness score and rear leg view index in crossbred dairy Cows. Indian Vet. J. 91, 59-60.

Received: 7 September 2016

Accepted: 13 November 2017

\section{SINGH, A., S. SINGH, D. K. GUPTA, B. K. BANSAL: Povezanost hromosti s ocjenom tjelesne kondicije, zdravljem vimena i kvalitetom mlijeka u krava križanki mliječnih pasmina. Vet. arhiv 88, 179-190, 2018.}

\section{SAŽETAK}

U istraživanje je uključeno 337 krava križanki za mlijeko, u različitim stadijima laktacije i s različitim paritetom. Krave su potjecale iz 13 slučajno odabranih farmi za proizvodnju mlijeka. Na temelju ljestvice do 5 bodova, kod krava je provedena procjena lokomocijske sposobnosti. Krave s blagom, umjerenom i jakom hromošću svrstane su u zajedničku skupinu hromih krava, a krave s ocjenom lokomocijske sposobnosti „0” u skupinu zdravih, nehromih krava. Ocjena tjelesne kondicije (BCS) u svih životinja također je procijenjena ljestvicom u rasponu od 1 do 5 bodova. Kravama s X-stavom stražnjih nogu (RLV) dodijeljena je ocjena „1“, a kravama s normalnim stavom stražnjih nogu dodijeljena je ocjena ,0“. U aseptičkim uvjetima od svake je krave prikupljen uzorak iz pojedinačnih četvrti vimena (QFM) i zajednički, miješani uzorak mlijeka. QFM je korišten za određivanje zdravstvenog statusa krava, a CC za procjenu broja somatskih stanica (SCC) i sastava mlijeka s obzirom na mast, SNF, bjelančevine i laktozu. Zaključeno je da su hrome krave imale signifikantno $(P<0,01)$ veći broj somatskih stanica SCC i lošiji zdravstveni status četvrti vimena u usporedbi sa zdravim kravama. RLV se povećao s povećanjem hromosti, iako nije utjecao na SCC i sastav mlijeka. Slično tomu, sastav mlijeka nije bio pod utjecajem hromosti. Hrome su krave imale slab BCS, što upućuje na negativnu povezanost s hromošću.

Ključne riječi: hromost; ocjena tjelesne kondicije; stav stražnjih nogu; broj somatskih stanica u mlijeku; sastav mlijeka 